\title{
Phylogenetic relationship of Turkish Apis mellifera subspecies based on sequencing of mitochondrial cytochrome $\mathrm{C}$ oxidase I region
}

\author{
F. Özdil and F. İlhan \\ Faculty of Agriculture, Selçuk University, Konya, Turkey \\ Corresponding author: F. Özdil \\ E-mail: fulyaozdil@selcuk.edu.tr
}

Genet. Mol. Res. 11 (2): 1130-1141 (2012)

Received November 11, 2011

Accepted March 5, 2012

Published April 27, 2012

DOI http://dx.doi.org/10.4238/2012.April.27.12

\begin{abstract}
Mitochondrial DNA sequence variation can be used to infer honey bee evolutionary relationships. We examined DNA sequence diversity in the cytochrome $\mathrm{C}$ oxidase I (COI or Cox 1 ) gene segment of the mitochondrial genome in 112 samples of Apis mellifera from 15 different populations in Turkey. Six novel haplotypes were found for the COI gene segment. There were eight variable sites in the COI gene, although only three were parsimony-informative sites. The mean pairwise genetic distance was $0.3 \%$ for the COI gene segment. Neighbor-joining (NJ) trees of the COI gene segment were constructed with the published sequences of $A$. mellifera haplotypes that are available in GenBank; the genetic variation was compared among the different honeybee haplotypes. The NJ dendogram based on the COI sequences available in GenBank showed that Eastern European races were clustered together, whereas the Mellifera and Iberian haplotypes were clustered far apart. The haplotypes found in this study were clustered together with A. mellifera ligustica and some of the Greek honey bees (accession Nos. GU056169 and GU056170) found in NCBI GenBank database. This study expands the knowledge about the mitochondrial $\mathrm{COI}$ region and presents the first comprehensive
\end{abstract}


sequence analysis of this region in Turkish honeybees.

Key words: Apis mellifera L.; DNA sequence diversity; COI; Turkey

\section{INTRODUCTION}

Based on morphometric and molecular approaches, the honeybee, Apis mellifera L., has been divided into 4 or 5 evolutionary lineages: the West European lineage (M), including northern Africa; the south and central African lineage (A); the north Mediterranean and Eastern European lineage $(\mathrm{C})$; the Near and Middle Eastern lineage $(\mathrm{O})$, and based on molecular studies, the eastern African lineage (Y) in which A. m. yemenitica from Ethiopia is included (Ruttner, 1988; Hall and Smith, 1991; Garnery et al., 1992; Arias and Sheppard, 1996; Kauhausen-Keller et al., 1997; Franck et al., 2000, 2001).

Based on morphometrics, the Near Eastern subspecies - Anatolian (A. m. anatoliaca), Caucasian (A. m. caucasica), and Iranian (A. m. meda) - had been grouped within the $\mathrm{O}$ branch (Ruttner, 1988; Kauhausen-Keller et al., 1997). However, mitochondrial DNA (mtDNA) analysis has shown that they belong to the C lineage (Smith et al., 1997; Palmer et al., 2000; Franck et al., 2000, 2001; Özdil et al., 2009a,b; Bouga et al., 2011). Morphometric analyses by Ruttner (1988) have indicated that nearly all of Turkey is occupied with $A$. m. anatoliaca but that A. m. caucasica is found in the northeastern part of Turkey, and A. m. meda is found in the southeastern part of Turkey. More recent mitochondrial studies of Turkish honeybees have shown that A. m. carnica is also found in the European part of Turkey called Thrace (Palmer et al., 2000), and A. m. syriaca is found in the southern part of the country near the Hatay region (Kandemir et al., 2006).

Length and sequence variations within the mitochondrial genome are widely used to study genetic diversity among populations with a high level of nucleotide substitution, conserved gene order and content and maternal inheritance (Avise et al., 1987; Hall and Smith, 1991; Garnery et al., 1992, 1993; Rokas et al., 2003). The maternal inheritance of mtDNA is more important in honeybees because all individuals of a colony are progeny of the queen, which means that their mtDNA is identical. As a result, a colony can be treated as an individual in analysis (Garnery et al., 1992).

Our knowledge of the mitochondrial genome of A. mellifera has been mainly focused on restriction fragment length polymorphism (RFLP) variability or sequencing of the transfer RNA (tRNA) ${ }^{\text {leu}}$-cytochrome $\mathrm{C}$ oxidase, COII region (formerly the COI-COII intergenic region). DraI restriction of the tRNA ${ }^{\text {leu}}$-COII region has revealed more than 60 different haplotypes, mainly in lineages A and M and fewer in lineage C (Garnery et al., 1992, 1993; Palmer et al., 2000; Franck et al., 2000, 2001; De La Rúa et al., 2002, 2004; Sušnik et al., 2004; Kozmus et al., 2007; Muňoz et al., 2009; Nedić et al., 2009; Özdil et al., 2009a; Magnus and Szalanski, 2010; Szalanski and Magnus, 2010). Although barcoding, a DNA-based identification system (Hebert et al., 2003), has mainly focused on sequence diversity in the COI region, we have little knowledge about the mitochondrial COI region beyond the tRNA ${ }^{\text {leu }}$-COII region in A. mellifera subspecies. Only the RFLP profile of the COI region (Bouga et al., 2005; Kekeçoğlu et al., 2009; Özdil et al., 2012) and the phylogenetic relationships of A. mellifera subspecies based on sequencing of this region have been reported (Tanaka et al., 2001; Marino et al., 2002a,b; Sheffield et al., 2009; Martimianakis et al., 2011). 
The objective of this research was to determine the genetic diversity and phylogenetic relationships of $A$. mellifera subspecies of Turkey through the COI gene segment sequencing. Length variations and nucleotide substitutions were compared with those found in other mitochondrial surveys. These results could be also useful in determining the genetic structure of $A$. mellifera.

\section{MATERIAL AND METHODS}

\section{Sampling and DNA extraction}

A total of 112 honeybees, each representing a different colony, were collected from 15 widespread locations in Turkey (Figure 1, Table 1). Workers were collected in $95 \%$ ethanol and subsequently air-dried. Total DNA was extracted from the thorax of each bee following the process of Hall (1990). The concentration and purification of genomic DNA was quantified with a NanoDrop ND-1000 spectrophotometer (Thermo Fischer Scientific, Inc., Wilmington, DE, USA) and $20 \mathrm{ng}$ genomic DNA was used for the polymerase chain reaction (PCR).

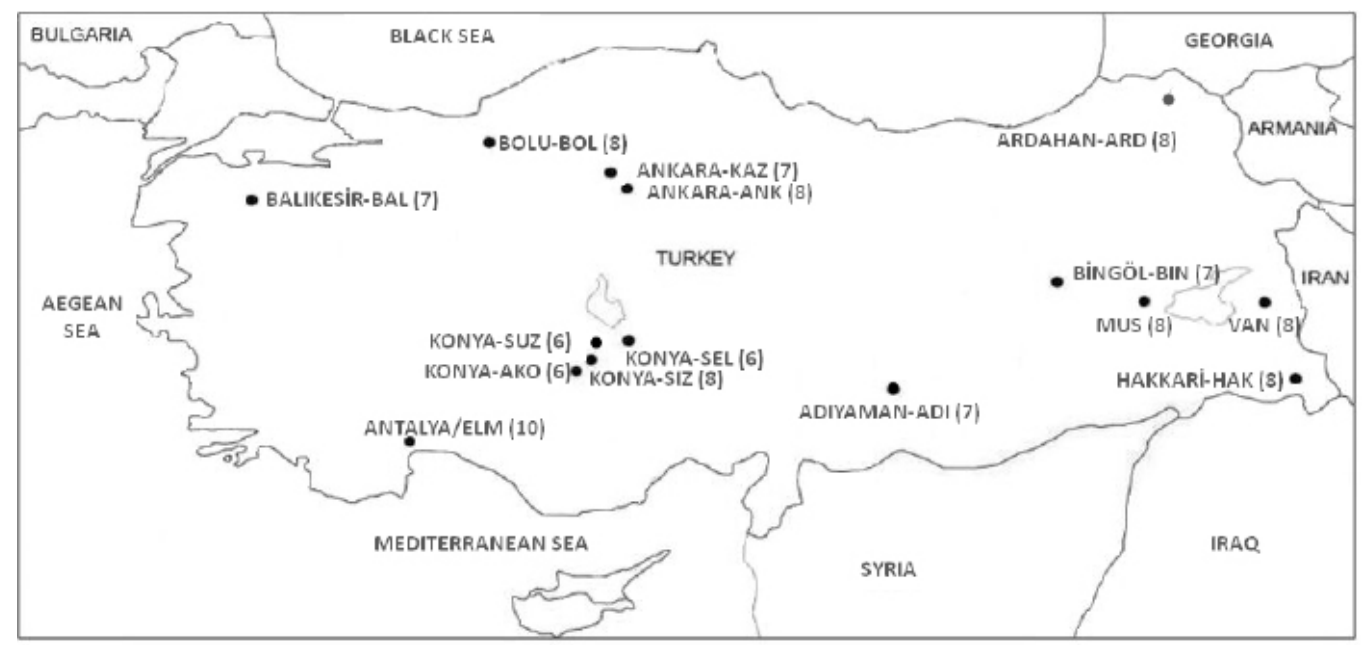

Figure 1. Sampling locations in Turkey. Number in parentheses show the number of colonies sequenced at each site.

\section{Sequence analysis}

The COI gene segments were amplified according to the method of Bouga et al. (2005). The PCR products were purified using a gel purification kit (QIAGEN) and sequenced in both directions on an ABI Prism 3130 automated sequencer (Applied Biosystems) using standard protocols. Sequences were aligned using Clustal X (Thompson et al., 1997). Molecular Evolutionary Genetics Analysis 5 (MEGA5) was used to estimate the similarity index and 
Table 1. Sampling localities, geographical positions and number of colonies used for sequencing.

\begin{tabular}{|c|c|c|c|c|}
\hline \multirow{2}{*}{$\begin{array}{l}\text { Locations } \\
\text { ADIYAMAN }\end{array}$} & \multirow{2}{*}{$\begin{array}{c}\text { Abbreviation of the locations } \\
\text { ADI }\end{array}$} & \multicolumn{2}{|c|}{ Geographical position } & \multirow{2}{*}{$\frac{\text { Colonies analyzed for sequence analysis }}{7}$} \\
\hline & & $37^{\circ} 46^{\prime} \mathrm{N}$ & $38^{\circ} 16^{\prime} \mathrm{E}$ & \\
\hline ARDAHAN & $\mathrm{ARD}$ & $41^{\circ} 03^{\prime} \mathrm{N}$ & $42^{\circ} 42^{\prime} \mathrm{E}$ & 8 \\
\hline ANKARA/KAZAN & KAZ & $39^{\circ} 58^{\prime} \mathrm{N}$ & $32^{\circ} 52^{\prime} \mathrm{E}$ & 7 \\
\hline ANKARA & ANK & $40^{\circ} 12^{\prime} \mathrm{N}$ & $32^{\circ} 41^{\prime} \mathrm{E}$ & 8 \\
\hline ANTALYA/ELMALI & ELM & $36^{\circ} 44^{\prime} \mathrm{N}$ & $29^{\circ} 56^{\prime} \mathrm{E}$ & 10 \\
\hline BALIKESIR & BAL & $39^{\circ} 39^{\prime} \mathrm{N}$ & $27^{\circ} 53^{\prime} \mathrm{E}$ & 7 \\
\hline BINGÖL & BIN & $39^{\circ} 00^{\prime} \mathrm{N}$ & $40^{\circ} 41^{\prime} \mathrm{E}$ & 7 \\
\hline BOLU/YIĞILCA & $\mathrm{BOL}$ & $40^{\circ} 58^{\prime} \mathrm{N}$ & $31^{\circ} 27^{\prime} \mathrm{E}$ & 8 \\
\hline HAKKARI & HAK & $37^{\circ} 35^{\prime} \mathrm{N}$ & $43^{\circ} 34^{\prime} \mathrm{E}$ & 8 \\
\hline KONYA/AKÖREN & $\mathrm{AKO}$ & $37^{\circ} 27^{\prime} \mathrm{N}$ & $32^{\circ} 22^{\prime} \mathrm{E}$ & 6 \\
\hline KONYA/SELÇUKLU & SEL & $37^{\circ} 57^{\prime} \mathrm{N}$ & $32^{\circ} 26^{\prime} \mathrm{E}$ & 6 \\
\hline KONYA/SIZMA & SIZ & $38^{\circ} 05^{\prime} \mathrm{N}$ & $32^{\circ} 24^{\prime} \mathrm{E}$ & 8 \\
\hline KONYA/SUZ* & SUZ & $38^{\circ} 02^{\prime} \mathrm{N}$ & $32^{\circ} 30^{\prime} \mathrm{E}$ & 6 \\
\hline MUŞ/VARTO & MUS & $39^{\circ} 17^{\prime} \mathrm{N}$ & $41^{\circ} 12^{\prime} \mathrm{E}$ & 8 \\
\hline VAN/GEVAS & VAN & $38^{\circ} 18^{\prime} \mathrm{N}$ & $43^{\circ} 06^{\prime} \mathrm{E}$ & 8 \\
\hline Total & & & & 112 \\
\hline
\end{tabular}

*SUZ = The Apiary of the Selçuk University.

evolutionary divergence between DNA sequences. Maximum parsimony (MP) and neighborjoining (NJ) analyses were performed using the same software, resulting in a consensus of the phylogenetic tree (Tamura et al., 2011).

We used a Bombus ignitus sequence (accession No. DQ870926) retrieved from GenBank as outgroup to root the trees for the construction of the phylogenetic trees. The various sequences obtained in this study have been deposited to GenBank with accession Nos. JN168656 to JN168661. The resulting sequences were compared to published sequences of the COI gene available in the NCBI database.

\section{RESULTS}

The sizes of the PCR-amplified COI segment of all samples studied were found to be approximately $989 \mathrm{bp}$ (primers excluded). Six novel haplotypes were revealed for the COI gene segment. The number of variable sites was 8 for COI, but only 3 were parsimony informative sites. The average pairwise genetic distance was $0.3 \%$ for the COI gene segment (Kimura, 1980).

Table 2 lists the various haplotypes of the COI segment that are available in the NCBI GenBank database and summarizes the sequence information, GenBank accession numbers, variable sites of these haplotypes, and additional haplotypes found in this study. The mtDNA nucleotide positions are taken from Crozier and Crozier (1993). The distribution of the haplotypes across honeybee populations is given Table 3 .

The trees drawn using the MP and NJ analyses exhibited nearly the same topology for the COI gene; therefore, only the NJ trees are presented here. Figure 2 depicts the phylogenetic relationships based on the COI sequences of all A. mellifera haplotypes that are available in GenBank. Less sequencing information is available about the mitochondrial COI region in A. mellifera L. than about the tRNA ${ }^{\text {leu}}-C O I I$ region, although genetic-based systems, primarily DNA barcoding studies, depend on the sequencing of the COI mitochondrial region. Figure 3 gives the NJ tree of the haplotypes obtained in this study. 


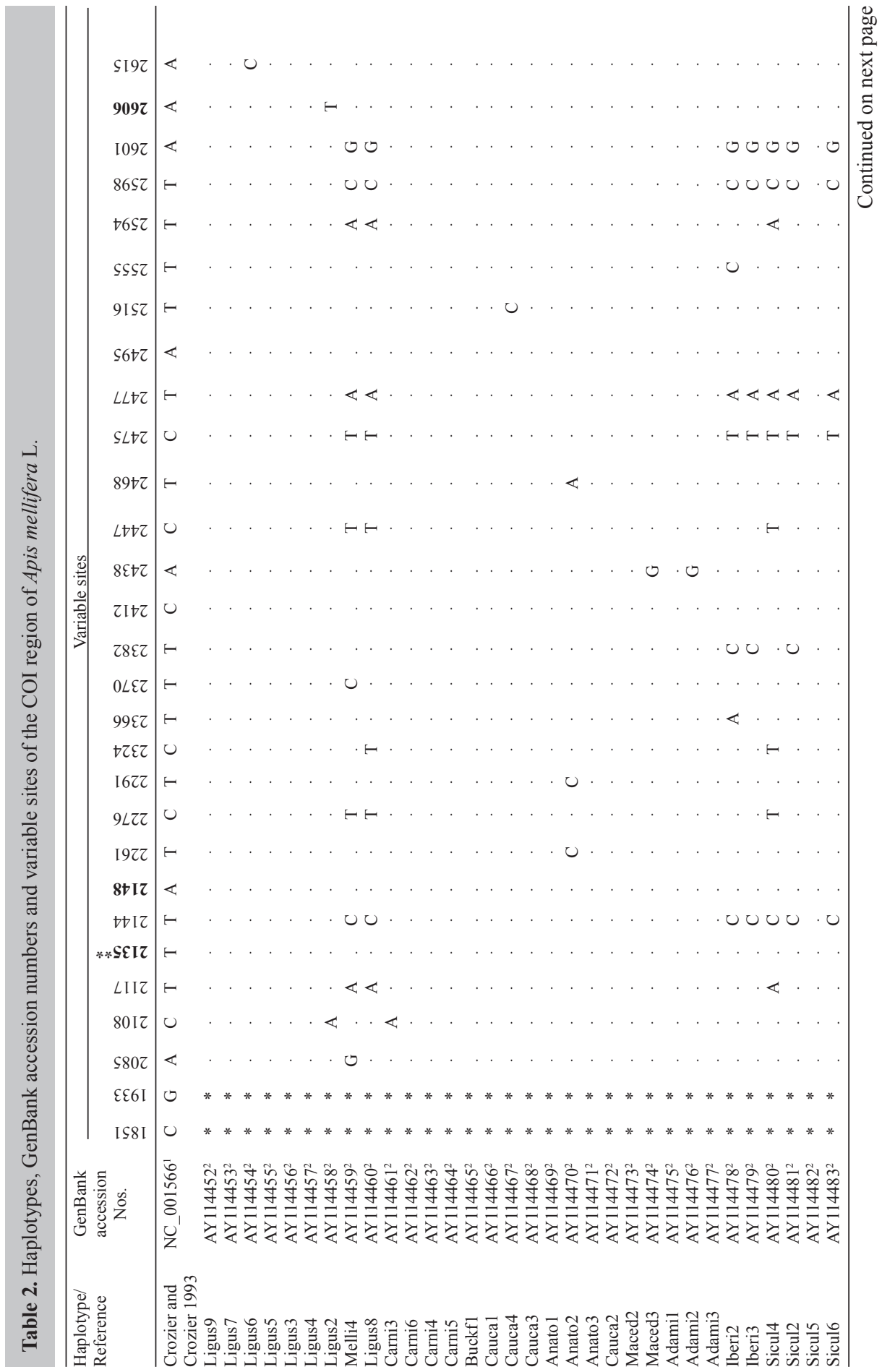




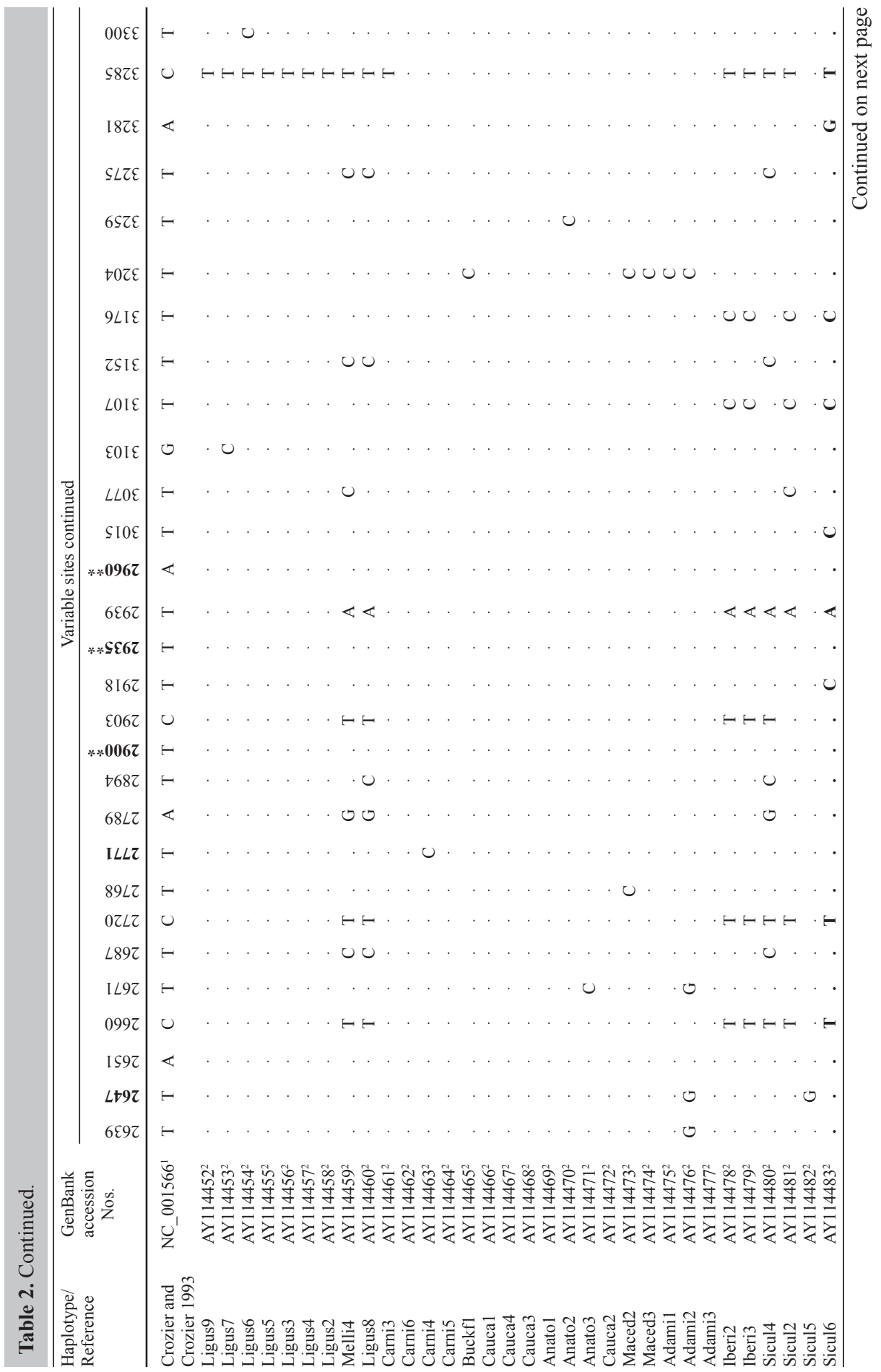




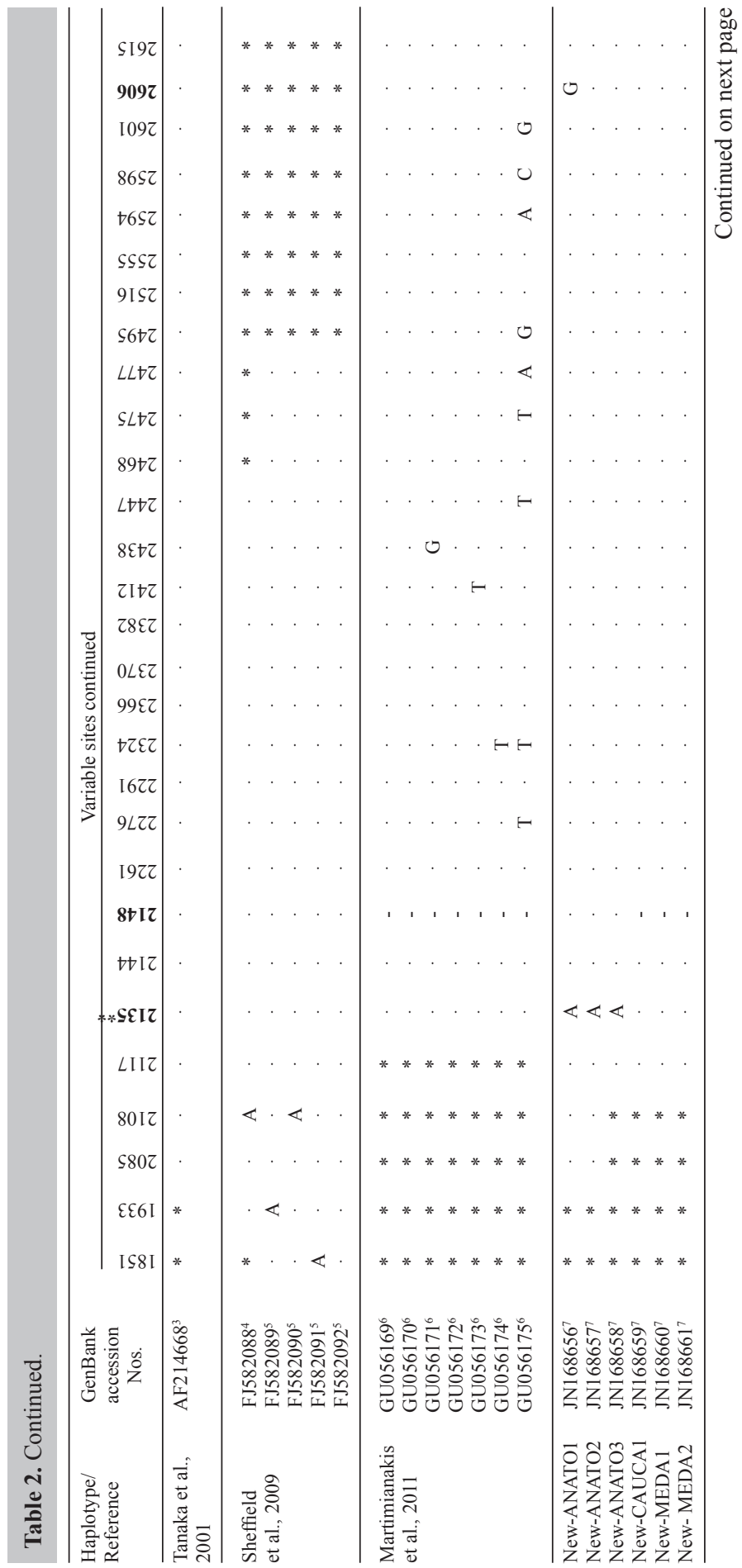


COI variation of Apis mellifera subspecies in Turkey

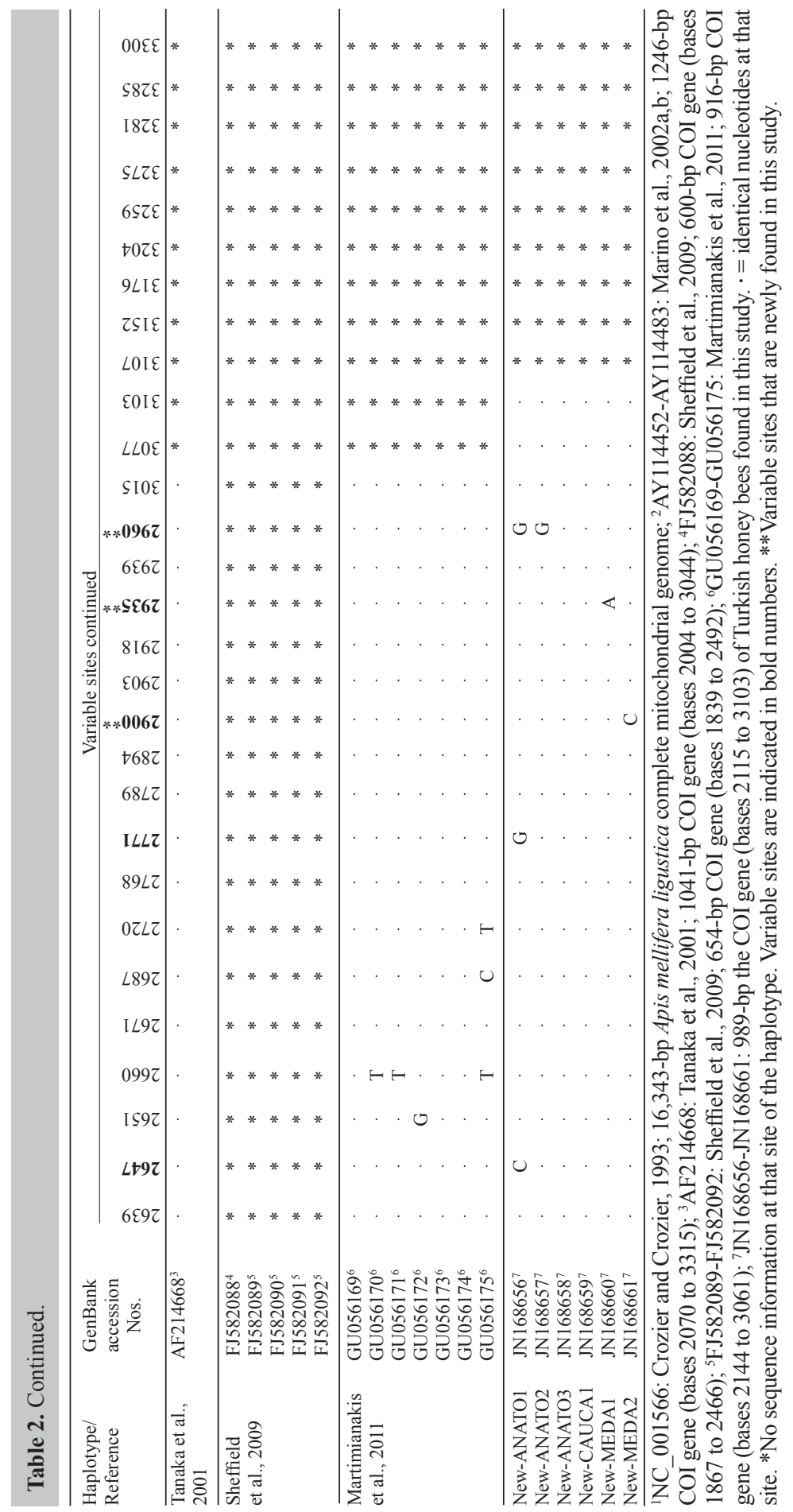


Table 3. The distribution of the haplotypes across honeybee populations.

\begin{tabular}{|c|c|c|c|c|c|c|c|c|c|c|c|c|c|c|c|c|c|c|}
\hline \multirow[t]{2}{*}{ Haplotypes } & \multirow{2}{*}{$\begin{array}{l}\text { GenBank } \\
\text { accession } \\
\text { Nos. }\end{array}$} & \multicolumn{17}{|c|}{ Populations } \\
\hline & & ADI & ARD & KAZ & ANK & ELM & BAL & BIN & BOL & HAK & $\mathrm{AKO}$ & SEL & SIZ & SUZ & MUS & VAN & Total & Frequency $(\%)$ \\
\hline ANATO1 & JN168656 & & & & & & & & & & & & 5 & & & & 5 & 4.5 \\
\hline ANATO2 & JN168657 & & & & & & 7 & & 8 & & & & & & & & 15 & 13.4 \\
\hline ANATO3 & JN168658 & & & & & 10 & & & & & 6 & 6 & 3 & 6 & & & 31 & 27.7 \\
\hline CAUCA1 & JN168659 & & 8 & 7 & 8 & & & & & & & & & & & & 23 & 20.5 \\
\hline MEDA1 & JN168660 & 7 & & & & & & 4 & & & & & & & 4 & 5 & 20 & 17.8 \\
\hline MEDA2 & JN168661 & & & & & & & 3 & & 8 & & & & & 4 & 3 & 18 & 16.1 \\
\hline Total & & 7 & 8 & 7 & 8 & 10 & 7 & 7 & 8 & 8 & 6 & 6 & 8 & 6 & 8 & 8 & 112 & \\
\hline
\end{tabular}

For abbreviations, see Table 1.

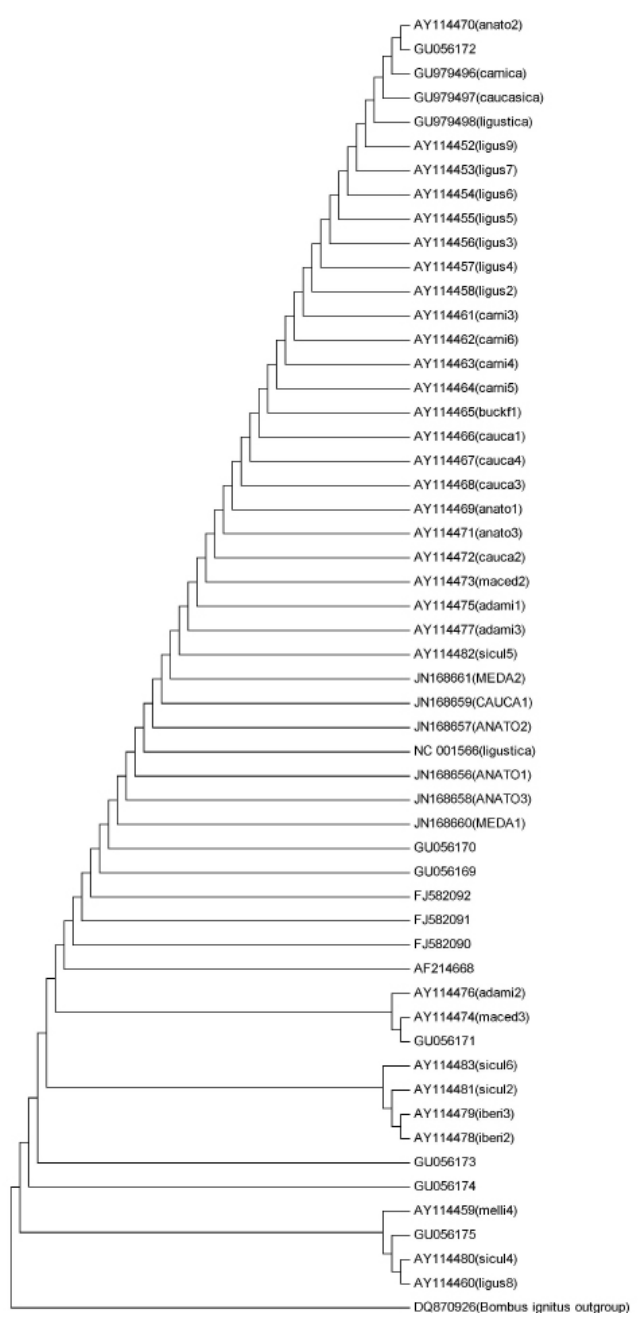

Figure 2. Neighbor-joining dendogram based on COI sequences of Apis mellifera haplotypes that are available in the NCBI GenBank database. Sequences obtained in this study are written in capital letters. 


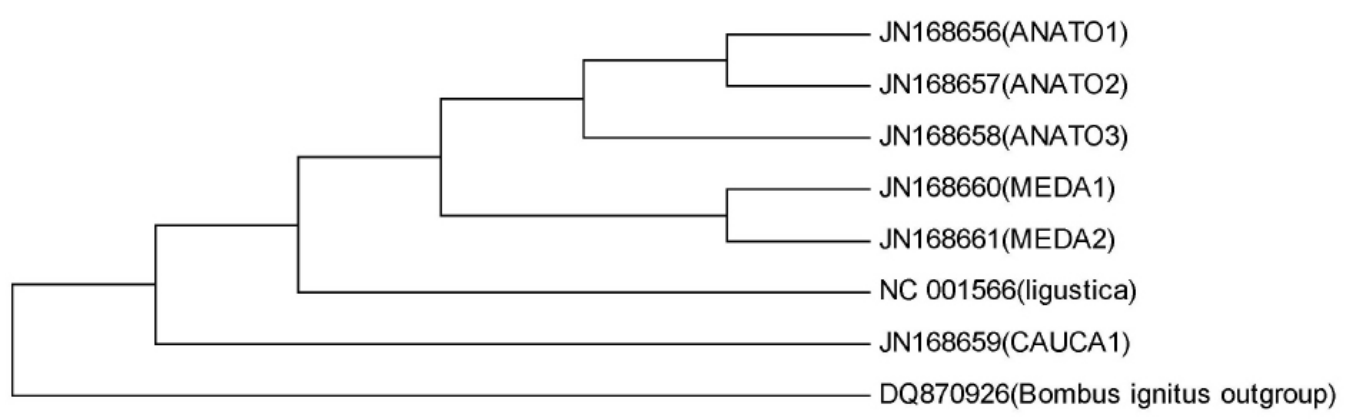

Figure 3. Neighbor-joining dendogram of COI sequences showing the relationships between the Turkish honeybee haplotypes obtained in this study.

\section{DISCUSSION}

Several mitochondrial studies of Turkish honeybee populations have been conducted (Smith et al., 1997; Palmer et al., 2000; Kandemir et al., 2006, Özdil et al., 2009a). Nearly all Turkish colonies analyzed by other surveys with restriction digests were found to belong to the $\mathrm{C}$ (Eastern European and Mediterranean) lineage. This finding was expected because the Turkish populations consist mainly of A. m. anatoliaca, A. m. caucasica, and A. m. meda.

Our previous study defined the phylogenetic relationships and PCR-RFLP profiles of Turkish honeybees based on 16srDNA, COI, and ND5 gene segments using several restriction enzymes (Özdil et al., 2012). In this study, we performed a comprehensive sequencing analysis of the COI gene segment to verify the genetic divergence in Turkish honeybee populations. More than 35 haplotypes in the COI region of $A$. mellifera were recorded to the NCBI GenBank database. Additionally, 6 new haplotypes were added in this study (see Tables 2 and 3). Three came from the Anatolian geographical locations, 2 from the Iranian, and one from the Caucasian. The ANATO1 haplotype was the rarest (4.5\%) in this study, found only in some of the Sizma (SIZ) population. The frequency of the ANATO2 haplotype was $13.4 \%$, found in the northern populations of Anatolia, Balıkesir (BAL), and Bolu (BOL). The highest haplotype frequency obtained was ANATO3, with a percentage of $27.7 \%$, in the populations in the southern and central region of Anatolia (Elmalı, Akören, Selçuklu, Sızma, and Konya (SUZ). The frequency of the CAUCA1 haplotype was $20.5 \%$ in northern and northeastern Anatolia (Kazan (KAZ), Ankara (ANK), and Ardahan (ARD), where A. m. caucasica predominates. The frequencies of MEDA1 and MEDA2 were 17.8 and $16.1 \%$, respectively, found in populations in the southeastern part of Turkey, where A. m. meda predominates (see Table 3).

In this study, nucleotide substitutions and a deletion site were observed in the COI region. A base substitution, which was first observed in this study at position $2135(\mathrm{~T} \rightarrow \mathrm{A})$, was obtained from all Anatolian races. A deletion site at position 2148, which had been previously reported in all haplotypes examined by Martimianakis et al. (2011), were detected in Caucasian and Iranian haplotypes but not in the Anatolian haplotype (see Table 2). The NJ dendrogram (see Figure 2) based on the COI sequences available in GenBank showed that that Eastern European races were clustered together, whereas the Mellifera and Iberian haplotypes were clustered far apart. The haplotypes found in this study were clustered together with 
A. m. ligustica and some of the Greek honeybees recorded in GenBank with accession Nos. GU056169 and GU056170.

To add to previous COI gene segment findings, we report herein the sequencing of the COI region in Turkish honeybees that belong to the C (Eastern European and Mediterranean) lineage and its comparison with that of various $A$. mellifera subspecies. Based on the sequence results, Turkish honeybee populations can be clearly classified into geographical locations in which A. m. caucasica and A. m. meda samples are classified in CAUCA1 and MEDA1MEDA2 haplotypes, respectively. These results suggest that the haplotypes maintain their native origin, which might be pure. High migratory beekeeping activity and the commercial activities of queen rearing in Turkey may result in the loss of genetic diversity, so the identification of the genetic structure of Turkish honeybee races and improvement of strategies to conserve them are important.

\section{ACKNOWLEDGMENTS}

We thank Dr. Saim BOZTEPE (Selçuk University, Faculty of Agriculture) and Dr. Mehmet Ali YILDIZ (Ankara University, Faculty of Agriculture) for providing insight and guidance to this paper.

\section{REFERENCES}

Arias MC and Sheppard WS (1996). Molecular phylogenetics of honey bee subspecies (Apis mellifera L.) inferred from mitochondrial DNA sequence. Mol. Phylogenet. Evol. 5: 557-566.

Avise JC, Arnold J, Ball RM, Bermingham E, et al. (1987). Intraspecific phylogeography: the mitochondrial DNA bridge between population genetics and systematics. Ann. Rev. Ecol. Syst. 18: 489-522.

Bouga M, Harizanis PC, Kilias G and Alahiotis S (2005). Genetic divergence and phylogenetic relationships of honey bee Apis mellifera (Hymenoptera: Apidae) populations from Greece and Cyprus using PCR-RFLP analysis of three mtDNA segments. Apidologie 36: 335-344.

Bouga M, Alaux C, Bienkowska M, Büchler R, et al. (2011). A review of methods for discrimination of honey bee populations as applied to European beekeeping. J. Apicult. Res. 50: 51-84.

Crozier RH and Crozier YC (1993). The mitochondrial genome of the honeybee Apis mellifera: complete sequence and genome organization. Genetics 133: 97-117.

De La Rúa P, Serrano J and Galián J (2002). Biodiversity of Apis mellifera populations from Tenerife (Canary Islands) and hybridisation with East European races. Biodivers. Conserv. 11: 59-67.

De La Rúa P, Hernández-García R, Pedersen BV, Galián J, et al. (2004). Molecular diversity of honeybee Apis mellifera iberica L. (Hymenoptera: Apidae) from western Andalusia. Archiv. Zootec. 53: 195-203.

Franck P, Garnery L, Solignac M and Cornuet JM (2000). Molecular confirmation of a fourth lineage in honeybees from the near east. Apidologie 31: 167-180.

Franck P, Garnery L, Loiseau A, Oldroyd BP, et al. (2001). Genetic diversity of the honeybee in Africa: microsatellite and mitochondrial data. Heredity 86: 420-430.

Garnery L, Cornuet JM and Solignac M (1992). Evolutionary history of the honey bee Apis mellifera inferred from mitochondrial DNA analysis. Mol. Ecol. 1: 145-154.

Garnery L, Solignac M, Celebrano G and Cornuet JM (1993). A simple test using restricted PCR-amplified mitochondrial DNA to study the genetic structure of Apis mellifera L. Experientia 49: 1016-1021.

Hall HG (1990). Parental analysis of introgressive hybridization between African and European honeybees using nuclear DNA RFLPs. Genetics 125: 611-621.

Hall HG and Smith DR (1991). Distinguishing African and European honeybee matrilines using amplified mitochondrial DNA. Proc. Natl. Acad. Sci. U. S. A. 88: 4548-4552.

Hebert PD, Ratnasingham S and deWaard JR (2003). Barcoding animal life: cytochrome c oxidase subunit 1 divergences among closely related species. Proc. Biol. Sci. 270 (Suppl 1): S96-S99.

Kandemir I, Kence M, Sheppard WS and Kence A (2006). Mitochondrial DNA variation in honey bee (Apis mellifera L.) 
populations from Turkey. J. Apicult. Res. Bee World 45: 33-38.

Kauhausen-Keller D, Ruttner F and Keller R (1997). Morphometric studies on the microtaxonomy of the species Apis mellifera L. Apidologie 28: 295-307.

Kekeçoğlu M, Bouga M, Soysal MI and Harizanis P (2009). Genetic divergence and phylogenetic relationships of honey bee populations from Turkey using PCR-RFLP's analysis of two mtDNA segments. Bulgarian J. Agric. Sci. 15: 589-597.

Kimura M (1980). A simple method for estimating evolutionary rates of base substitutions through comparative studies of nucleotide sequences. J. Mol. Evol. 16: 111-120.

Kozmus P, Stevanović J, Stanimirović Z, Stojić V, et al. (2007). Analysis of mitochondrial DNA in honey bees (Apis mellifera) from Serbia. Acta Vet. 57: 465-476.

Magnus R and Szalanski AL (2010). Genetic evidence for honey bees (Apis mellifera L.) of middle eastern lineage in the United States. Sociobiology 55: 285-296.

Marino A, Sabatini AG, Carpana E, Lodesani M, et al (2002a). ND2 and CO1 mitochondrial genes in Apis mellifera L.: A Molecular Approach to Mediterranean Population Monitoring. In: Proceedings of the Sixth European Bee Conference: "Bees Without Frontiers". University of Wales Institute, Cardiff, 157.

Marino A, Sabatini AG, Carpana E and Mantovani B (2002b). Analysis of mitochondrial genes NDH2, CO1 and 16S for the characterization of Apis mellifera populations. Insects Soc. Life 4: 87-92.

Martimianakis S, Klossa-Kilia E, Bouga M and Kilias G (2011). Phylogenetic relationships of Greek Apis mellifera subspecies based on sequencing of mtDNA segments (COI and ND5). J. Apicult. Res. 50: 42-50.

Muňoz I, Dall'Olio R, Lodesani M and De La Rúa P (2009). Population genetic structure of coastal Croatian honeybees (Apis mellifera carnica). Apidologie 40: 617-626.

Nedić N, Stanisavljević L, Mladenović M and Stanisavljević J (2009). Molecular characterization of the honeybee Apis mellifera carnica in Serbia. Arch. Biol. Sci. Belgrade 61: 587-598.

Özdil F, Yildiz MA and Hall HG (2009a). Molecular characterization of Turkish honey bee populations (Apis mellifera L.) inferred from mitochondrial DNA RFLP and sequence results. Apidologie 40: 570-576.

Özdil F, Fakhri B, Meydan H, Yildiz MA, et al. (2009b). Mitochondrial DNA variation in the CoxI-CoxII intergenic region among Turkish and Iranian honey bees (Apis mellifera L.). Biochem. Genet. 47: 717-721.

Özdil F, Aytekin I, Ilhan F and Boztepe S (2012). Genetic variation in Turkish honeybees Apis mellifera anatoliaca, A. $m$. caucasica, A. m. meda (Hymenoptera: Apidae) inferred from RFLP analysis of three mtDNA regions (16S rDNACOI-ND5). Eur. J. Entomol. 109: 161-167.

Palmer MR, Smith DR and Kaftanoglu O (2000). Turkish honeybees: genetic variation and evidence for a fourth lineage of Apis mellifera mtDNA. J. Hered. 91: 42-46.

Rokas A, Ladoukakis E and Zouros E (2003). Animal mitochondrial DNA recombination revisited. Tree 18: 411-417.

Ruttner F (1988). Biogeography and Taxonomy of Honeybees. Springer-Verlag, Berlin, 284.

Sheffield CS, Hebert PD, Kevan PG and Packer L (2009). DNA barcoding a regional bee (Hymenoptera: Apoidea) fauna and its potential for ecological studies. Mol. Ecol. Resour. 9 (Suppl s1): 196-207.

Smith DR, Slaymaker A, Palmer M and Kaftanoğlu O (1997). Turkish honey bees belong to the east Mediterranean mitochondrial lineage. Apidologie 28: 269-274.

Sušnik S, Kozmus P, Poklukar J and Meglić V (2004). Molecular characterisation of indigenous Apis mellifera carnica in Slovenia. Apidologie 35: 623-636.

Szalanski AL and Magnus RM (2010). Mitochondrial DNA characterization of Africanized honey bee (Apis mellifera L.) populations from the USA. J. Apicult. Res. Bee World 49: 177-185.

Tamura K, Peterson D, Peterson N, Stecher G, et al. (2011). MEGA5: Molecular Evolutionary Genetics Analysis using maximum likelihood, evolutionary distance, and maximum parsimony methods. Mol. Biol. Evol. 28: 2731-2739.

Tanaka H, Roubik DW, Kato M, Liew F, et al. (2001). Phylogenetic position of Apis nuluensis of northern Borneo and phylogeography of $A$. cerana as inferred from mitochondrial DNA sequences. Insect. Soc. 48: 44-51.

Thompson JD, Gibson TJ, Plewniak F, Jeanmougin F, et al. (1997). The CLUSTAL_X windows interface: flexible strategies for multiple sequence alignment aided by quality analysis tools. Nucleic Acids Res. 25: 4876-4882. 